\title{
Operacja w obronie jezydów w 2014 roku: od interwencji na zaproszenie do interwencji humanitarnej i odpowiedzialności za ochronę?
}

\author{
Operation to protect the Yezidis in 2014: \\ from intervention by invitation \\ to humanitarian intervention \\ and responsibility to protect?
}

\section{Arkadiusz Domagała*}

\begin{abstract}
Abstrakt
$\mathrm{W}$ artykule przedstawiona jest interwencja w obronie jezydów zapoczątkowana w sierpniu 2014 roku w północnym Iraku. Podmiotem operacji były przede wszystkim Stany Zjednoczone dysponujące zgodą irackiego rządu na prowadzenie działań zbrojnych na rzecz integralności terytorialnej oraz ochrony obywateli Iraku. Autor artykułu dowodzi, że w operacji w obronie jezydów, wbrew powszechnym przekonaniom, można odnaleźć znacznie więcej elementów interwencji humanitarnej niż odpowiedzialności za ochronę. W tym celu
\end{abstract}

* Instytut Politologii, Uniwersytet iD https://orcid.org/0000-0003-4974-7618.

\begin{abstract}
The article presents an issue of the intervention to protect the Yezidis started in August 2014 in northern Iraq. The United States, the crucial intervener, had the consent of the Iraqi government to conduct military operations in favour of its territorial integrity and to protect Iraqi citizens. However, there were also other interveners and the military actions took place nor only in the Iraqi territory. The author of the article argues that in the military operation to protect the Yezidi people, much more elements of humanitarian intervention than of
\end{abstract}

Wrocławski (arkadiusz.domagala@uwr.edu.pl); 
poszczególne komponenty operacji w obronie jezydów zostały zaprezentowane przez pryzmat koncepcji interwencji humanitarnej i odpowiedzialności za ochronę.

Słowa kluczowe: jezydzi, interwencja humanitarna, odpowiedzialność za ochronę, Irak the responsibility to protect can be found. Thus the various components of the military action in 2014 to protect the Yezidis were presented through the prism of ideas of humanitarian intervention and responsibility to protect.

Key words: Yezidis, humanitarian intervention, responsibility to protect, Iraq

Celem podjętym $\mathrm{w}$ artykule jest zakwalifikowanie interwencji $\mathrm{w}$ obronie jezydów w 2014 roku do określonego mechanizmu obejmującego użycie siły w celach humanitarnych. Akcja w dystrykcie Sindżar została zapoczątkowana jako tzw. interwencja na zaproszenie i miała charakter operacji humanitarnej (głównie ewakuacyjnej). Pojawiające się wątpliwości dotyczą tego, czy można ją potraktować także jako przykład interwencji humanitarnej bądź odpowiedzialności za ochronę (lub obu typów działania naraz). Zastosowane w artykule metody badawcze sytuują się $\mathrm{w}$ ramach metod komparatystycznych $\mathrm{z}$ wykorzystaniem typu idealnego oraz analizy instytucjonalno-prawnej.

Pierwsza część artykułu zostanie poświęcona zobrazowaniu sytuacji w regionie oraz działaniom tzw. Państwa Islamskiego ${ }^{1}$, a następnie naruszeniom praw człowieka i międzynarodowej reakcji na działania ISIS wobec ludności w dystrykcie Sindżar. W kolejnej sekcji zarysowana zostanie różnica między koncepcją interwencji humanitarnej a odpowiedzialności za ochronę. Finalną częścią artykułu jest próba formalnoprawnej kwalifikacji naruszeń wobec jezydów oraz operacji humanitarnej $\mathrm{w}$ regionie.

W 2013 roku Państwo Islamskiego Iraku i Lewantu (ISIL) przejęło kontrolę nad znaczącą częścią wschodniej Syrii. Prowadzona ofensywa skutkowała konfliktem z niemal wszystkimi stronami wojny domowej: umiarkowaną opozycją (głównie Narodową Koalicją na rzecz Sił Rewolucyjnych i Opozycyjnych oraz Armią Wolnej Syrii), radykalnymi organizacjami islamskimi Dżabat al-Nusra i Frontem Islamskim, kurdyjskimi organizacjami skupionymi wokół Demokratycznych Sił Syryjskich (SDF) oraz siłami wiernymi prezydentowi Baszarowi al-Asadowi i jego sojusznikom. Działaniom ISIS w Syrii towarzyszyły naruszenia praw człowieka na dużą skalę: zabójstwa, porwania, wymuszone konwersje, niszczenie mienia. Na początku 2014 roku siły Państwa Islamskiego rozpoczęły ofensywę w kierunku wschodnim, przekraczając granicę z Irakiem. Oddziały ISIS posuwały się błyskawicznie w stronę Bagdadu, obejmując kontrolę nad

${ }^{1} \mathrm{~W}$ artykule stosowane będzie konsekwentnie określenie Państwo Islamskie. W czerwcu 2014 r. Państwo Islamskie w Iraku i Lewancie (ISIL) ogłosiło utworzenie kalifatu i proklamowało niezależność jako Państwo Islamskie (ISIS). 
głównymi punktami strategicznymi w prowincji al-Anbar, zdobywając między innymi Faludżę, odległą od stolicy państwa o około $60 \mathrm{~km}$. Do sierpnia 2014 roku ISIS opanowało większość prowincji Niniwa (w tym drugie co do wielkości miasto w Iraku - Mosul) oraz Salah ad-Din.

Postępom armii Państwa Islamskiego towarzyszyło wprowadzanie nowego porządku społeczno-politycznego, którego nieodłącznym elementem było naruszanie praw jednostek. W największym stopniu uwidaczniało się to na obszarach zróżnicowanych etnicznie i wyznaniowo. O ile w prowincjach al-Anbar i Salah ad-Din niemal zupełnie dominowała arabska ludność sunnicka, nierzadko sympatyzująca z ugrupowaniami salafickimi powstałymi po upadku rządów Saddama Husajna, o tyle w prowincji Niniwa zamieszkiwało wiele wspólnot niemuzułmańskich — przede wszystkim jezydzi, ale również chrześcijańscy Asyryjczycy czy Chaldejczycy. Dodatkowo na muzułmańską ludność składały się także wrogo nastawione do ISIS grupy kurdyjskie, turkmeńskie i szyickie. Presja ISIS powodowała ucieczkę miejscowych grup z dotychczasowych siedzib (np. wspólnot chrześcijańskich z Mosulu) albo, rzadziej, napotykała opór — jedno i drugie prowadziło nieuchronnie do łamania praw człowieka.

Jedną z najczęściej atakowanych mniejszości byli jezydzi — przedstawiciele synkretycznej, monoteistycznej religii, pochodzenia kurdyjskiego - zamieszkujący przede wszystkim terytorium współczesnego Iraku (głównie w prowincji Niniwa). Szczególna niechęć radykalnych sunnitów do jezydów jest przede wszystkim konsekwencją sposobu postrzegania przez tych pierwszych Anioła Pawia (Melek Taus, Peacock Angel). Dla jezydów jest on emanacją woli Boga na ziemi, stąd oddawana mu cześć. Tymczasem w narracji sunnickiej Anioł Paw jest traktowany jako Szatan, sprzeciwiający się woli Boga (gdyż nie składając pokłonu Adamowi, uległ pysze i nie usłuchał Boga)². W konsekwencji jezydzi postrzegani są przez salafickie ugrupowania, takie jak ISIS, jako czciciele Szatana. Kilkusettysięczna mniejszość jezydzka w naturalny sposób stała się przeciwnikiem dokonującego ofensywy polityczno-militarnej Państwa Islamskiego i grupą narażoną na poważne i masowe naruszenia praw człowieka. Biorąc pod uwagę profil ideologiczny oraz wcześniejsze działania polityczne i traktowanie ludności cywilnej w Syrii, można było domniemywać, że ISIS i jego członkowie będą dokonywać na szeroką skalę mordów (szczególnie w sytuacji oporu ludności) i porwań, a także wymuszać konwersję ${ }^{3}$ Przewidywania badaczy, po-

${ }^{2}$ Według jezydów Melek Taus, w imieniu Boga i pogodzony z nim, rządzi światem jako przywódca archaniołów. Patrz m.in. G.S. Asatrian, V. Arakelova: The Religion of the Peacock Angel. The Yezidis and their Spirit World. Abingdon-New York 2014, s. 9-36.

3 Iraq Crisis: ISIS Militiants Threaten UK, Says Cameron. "BBC News", 19 June 2014 https://www.bbc.com/news/uk-politics-27898724 (dostęp:20.06.2018); M.A. SALIH: Iraq's Christians Seek Refuge with Kurds. „Al Jazeera News”, 26 June 2014 — https://www.aljazeera.com/ news/middleeast/2014/06/iraq-christians-seek-refuge-with-kurds-2014624867119947.html (dostęp: 20.06.2018). We wcześniejszych latach na terenach zamieszkiwanych przez jezydów 
lityków i mediów zaczęły się spełniać wraz z obecnością sił ISIS na terenach będących siedzibami jezydów, a tym samym pojawiło się pytanie o możliwą międzynarodową reakcję na ryzyko poważnych naruszeń.

Kulminacja naruszeń praw człowieka na terytoriach zamieszkiwanych przez jezydów nastąpiła w sierpniu 2014 roku. Na początku miesiąca oddziały ISIS weszły do dystryktu Sindżar, a już 3 sierpnia opanowały główne miasto regionu - przeszło 80-tysięczny Sindżar. Ani wojska irackie, ani wojska kurdyjskie nie były w stanie powstrzymać postępów ISIS i wycofały się zarówno z miasta, jak i z dystryktu. Ludności jezydzkiej generalnie stawiano ultimatum: konwersja na islam i podporządkowanie się Państwu Islamskiemu (co de facto oznaczało zgodę na dalsze naruszenia, np. natury seksualnej) lub śmierć. Reakcją jezydów (a także innych grup mniejszościowych) była przede wszystkim próba ucieczki. W wyniku ofensywy ISIS w północnej części Iraku (m.in. w dystrykcie Sindżar) swoje domostwa w pierwszych dniach sierpnia opuściło 200 tys. osób, a całkowita liczba uchodźców w regionie przekraczała 400 tys. ludzi ${ }^{4}$. Wrogie działania ISIS dotykały także dobytku i kultury materialnej jezydów niszczono ich domostwa, inwentarz oraz miejsca kultu.

Zmuszaniu do przejścia na islam towarzyszyły mordy na ludności cywilnej, zarówno na mężczyznach, jak i na kobietach. Ocenia się, że w wyniku zabójstw dokonanych przez siły ISIS zginęło około $3-5$ tys. osób ${ }^{5}$. W trakcie krótkotrwałej okupacji terenów zamieszkanych przez jezydów w dystrykcie Sindżar doszło do wielu masowych mordów, potwierdzanych następnie przez odkrywanie zbiorowych mogił, między innymi w Qiniyeh (ok. 80 ofiar śmiertelnych), Hardan (ok. 250 ofiar śmiertelnych), Kocho (ok. 400-700 ofiar śmiertelnych), więzieniu Tal Afar (ok. 200 ofiar śmiertelnych), Jdali (ok. 50 ofiar śmiertelnych) 6 .

dochodziło już do ataków, o które oskarżane były irackie radykalne ugrupowania sunnickie. Patrz m.in. M. Howard: "They won't stop until we are all wiped out”. Among the Yezidi, a People in Mourning. "The Guardian", 18 August 2007 — https://www.theguardian.com/ world/2007/aug/18/iraq.topstories3 (dostęp: 20.06.2018).

${ }^{4}$ Liczbę wszystkich uchodźców (głównie wewnętrznych) w trakcie ofensywy ISIS ocenia się na nawet 830 tys. osób. Amnesty International: Ethnic Cleansing on a Historic Scale: Islamic State's Systematic Targeting of Minorities in Northern Iraq. London 2014, s. 5.

${ }^{5}$ V. Cetorelli, I. Sasson, N. Shabila, G. Burnham: Mortality and Kidnapping Estimates for the Yezidis Population in the Area of Mount Sinjar, Iraq, in August 2014: A Retrospective Household Survey. „PLoS Med” 2017, Vol. 14, No 5 - https://doi.org/10.1371/journal.pmed.1002297 (dostęp: 20.06.2018).

${ }^{6}$ Patrz m.in. Amnesty International: Ethnic Cleansing..., s. 7-13; Report of the Office of the United Nations High Commissioner for Human Rights on the human rights situation in Iraq in the light of abuses committed by the so-called Islamic State in Iraq and the Levant and associated groups. UN Doc. A/HRC/28/18, 13 March 2015, s. 6, para. 19; Human Rights Office of the High Commissioner for Human Rights \& United Nations Assistance Mission for IraQ: Report on the Protection of Civilians in Armed Conflict in Iraq: 6 July - 10 September 2014. October 2014, s. 14 - https://www.ohchr.org/Documents/Countries/IQ/UNAMI_OHCHR_POC_Report_FINAL_6July_10September2014.pdf 
Jak wskazują źródła, zmiana wyznania na islam nie chroniła skutecznie przed śmiercią?.

Niemal 7 tys. osób zostało z dystryktu Sindżar uprowadzonych ${ }^{8}$. Oddziały Państwa Islamskiego stosowały tę praktykę w szczególności względem kobiet, które następnie były albo więzione i wykorzystywane w celach seksualnych lub ekonomicznych (np. dla okupu bądź handlu), albo zmuszane do konwersji (i następnie brane jako „narzeczone” i ,żony” dla członków ISIS), albo mordowane'. Porwania stosowano również względem dzieci, które z dużym prawdopodobieństwem miały być wykorzystywane jako „dzieci-żołnierze” (także do celów terrorystycznych) ${ }^{10}$. Jezydzi niezwykle często ratując się przed śmiercią, porwaniami, zgwałceniami i wymuszeniami, wybierali ucieczkę na górę Sindżar, która, ze względu na niską mobilność ludności cywilnej oraz uwarunkowania geograficzne, wydawała się dobrym miejscem schronienia. Podłużna góra w prowincji Niniwa, której długość liczy około 70 kilometrów, o najwyższym wzniesieniu 1463 metry n.p.m., dawała ułudę bezpieczeństwa. Oddziały ISIS w kilka dni po wkroczeniu do dystryktu zamknęły okrążenie wokół góry, na którą udało się około 50 tys. jezydów, głównie z miasta z Sindżar i okolic. Trudne warunki - wysoka temperatura (nawet 45 stopni Celsjusza), ekspozycja na słońce, brak wody i jedzenia — stwarzały poważne ryzyko dla ludności ${ }^{11}$. Według relacji biura Wysokiego Komisarza ds. Uchodźców tygodniowy pobyt na górze skutkował śmiercią co najmniej kilkudziesięciu dzieci, głównie z pragnienia oraz pokąsania przez węże i skorpiony ${ }^{12}$.

(dostęp: 20.06.2018). Liczba ofiar masakry w Kocho jest dyskusyjna: w raporcie HRCHR i UNAMI podano liczbę 700 osób, raporty organizacji pozarządowych wskazują na niższą liczbę.

${ }^{7}$ Report of the Office of the United Nations High Commissioner for Human Rights on the human rights situation in Iraq..., s. 6, para. 18.

${ }^{8}$ V. Cetorelli, I. Sasson, N. Shabila, G. Burnham: Mortality and Kidnapping Estimates..., s. 12.

${ }^{9}$ Human Rights Watch: Iraq: Forced Marriage, Conversion for Yezidis. Victims, Witnesses Describe Islamic State's Brutality to Captives. 11 October 2014 — https://www.hrw. org/news/2014/10/11/iraq-forced-marriage-conversion-yezidis (dostęp: 20.06.2018); C. ОтTEN: Slaves of Isis. The Long Walk of the Yazidi Women. “The Guardian”, 25 July 2017 — https:// www.theguardian.com/world/2017/jul/25/slaves-of-isis-the-long-walk-of-the-yazidi-women (dostęp: 20.06.2018).

${ }^{10}$ Human Rights Watch: Iraq: Forced Marriage...

${ }^{11}$ L. Morris: Islamic State Seizes Town of Sinjar, Pushing out Kurds and Sending Yazidis Fleeing. "The Washington Post", 3 August 2014 — https://wapo.st/2Kquasd (dostęp: 23.06.2018).

${ }^{12}$ N. Colt: Thousands Find Shelter in Iraqi Kurdistan after Escaping Mount Sinjar. UNHCR, 12 August 2014 - http://www.unhcr.org/news/latest/2014/8/53e9fe2d9/thousands-find-shelter-iraqi-kurdistan-escaping-mount-sinjar.html (dostęp: 21.06.2018). Według raportu HRCHR i UNAMI w wyniku odwodnienia zmarło 200 dzieci. Human Rights OfFICE OF the High Commissioner for Human Rights \& United Nations Assistance Mission for IRAQ: Report on the Protection of Civilians..., s. 14. 
Sytuację jezydów, zwłaszcza ataki na ludność dystryktu Sindżar oraz masowe uchodźstwo (w tym na górę Sindżar), powszechnie traktowano jako poważne wyzwanie dla społeczności międzynarodowej. Przekonanie o konieczności działania było potęgowane przez powszechną ocenę naruszeń wobec mniejszości jako ludobójstwa. Presja mediów i organizacji międzynarodowych wzmagały humanitarny imperatyw i czyniły interwencję w obronie jezydów z dnia na dzień coraz bardziej prawdopodobną.

7 sierpnia 2014 roku prezydent Barack Obama oświadczył, że Stany Zjednoczone rozpoczynają dwie operacje zbrojne $\mathrm{w} \mathrm{Iraku}^{13}$. Pierwsza $\mathrm{z}$ nich polegała na autoryzowaniu uderzeń $\mathrm{z}$ powietrza $\mathrm{w}$ celu ochrony amerykańskiego personelu rozmieszczonego w Iraku, a druga — na ,humanitarnym wysiłku w celu pomocy tysiącom obywateli irackich uwięzionym na górze, pozbawionym jedzenia i wody, a skazanym na pewną śmierć"'14. Prezydent Obama podkreślił, że czyny ISIS nie mogą pozostać bez odpowiedzi, a USA, działając „rozważnie i odpowiedzialnie”, są w stanie zapobiec „potencjalnemu” ludobójstwu ${ }^{15}$. Tego samego dnia Stany Zjednoczone rozpoczęły zrzuty pomocy humanitarnej ludności na górze Sindżar - ogółem dostarczono ponad 130 tys. litrów wody oraz ponad 114 tys. racji żywnościowych ${ }^{16}$. Pomoc humanitarną dla uwiezionych na górze Sindżar dostarczyły także Wielka Brytania oraz Australia.

9 sierpnia Stany Zjednoczone rozpoczęły ataki z powietrza na pojazdy i jednostki Państwa Islamskiego zagrażające ludności jezydzkiej ${ }^{17}$. Między 9 a 11 sierpnia współpracujące z sobą siły kurdyjskie PKK (Partiya Karkerên Kurdistanê — Partia Pracujących Kurdystanu) oraz YPG (Yekîneyên Para-

13 The White House Office of the Press Secretary: Statement by the President. 7 August 2014 - https://obamawhitehouse.archives.gov/the-press-office/2014/08/07/ statement-president (dostęp: 21.06.2018).

${ }^{14}$ Ibidem.

15 Ibidem.

${ }^{16} \mathrm{~W}$ ciągu pierwszego dnia zrzutów dostarczono 14 tys. litrów wody oraz 16 tys. racji żywnościowych. We wsparciu humanitarnym uczestniczyły również jednostki armii irackiej. Patrz m.in. I. Watson, B. Starr, C.J. Carter: Officials: More U.S. Advisers Being Sent to Iraq. "CNN News", 13 August 2014 — https://edition.cnn.com/2014/08/12/world/meast/iraq-crisis/index.html?hpt=hp_t1 (dostęp: 21.06.2018); United Nations High Commissioner fOR Human Rights \& United Nations Assistance Mission for IraQ: A Call for Accountability and Protection: Yezidi Survivors of Atrocities Committed by ISIL. August 2016 - https:// www.ohchr.org/Documents/Countries/IQ/UNAMIReport12Aug2016_en.pdf, s. 6 (dostęp: 21.06.2018).

${ }_{17}$ Stany Zjednoczone przeprowadzały bombardowania i dostarczały wsparcia z powietrza dla oddziałów kurdyjskich i irackiej armii systematycznie od 8 sierpnia 2014 roku. Stanowi to początek interwencji i budowy koalicji przeciwko ISIS. A.J. Rubin, T. Arango, H. Cooper: U.S. Jets and Drones Attack Militants in Iraq Hoping to Stop Advance. "New York Times", 8 August 2014 — https://www.nytimes.com/2014/08/09/world/middleeast/iraq. html (dostęp: 21.06.2018). 
stina Gel - Ludowe Jednostki Ochrony), przy wsparciu USA i Peshmerga (sił zbrojnych regionalnego kurdyjskiego rządu w Iraku) utworzyły korytarz, umożliwiający opuszczenie góry Sindżar przez jezydów. Jednostki kurdyjskie, korzystając z ciężarówek, traktorów i innych pojazdów, zdołały zapewnić ewakuację około 35 tys. jezydów, którzy uszli na tereny kontrolowane przez siły kurdyjskie w Syrii, a następnie do irackiego Kurdystanu. Mimo dużego ryzyka dla ochraniających sił i ludności cywilnej akcja zakończyła się sukcesem ${ }^{18}$. Jeszcze w trakcie akcji ewakuacyjnej członkowie oddziałów amerykańskich i brytyjskich w specjalnej akcji na górze Sindżar ocenili zagrożenia dla jezydów i konieczność dalszego zaangażowania na rzecz ludności cywilnej w rejonie. W konsekwencji 14 sierpnia Stany Zjednoczone, podsumowując dotychczasowe działania na rzecz jezydów, stwierdziły, że dalsza interwencja i operacja ewakuacyjna są niepotrzebne ${ }^{19}$. Spośród osób, które zdecydowały się nie opuszczać góry Sindżar (ok. 5 tys. osób) przeważali pasterze i ludność gotowa pozostać w dotychczasowym miejscu. Decyzja USA spotkała się z częściową krytyką regionalnych (irackich) ośrodków władzy i organizacji pozarządowych.

W październiku 2014 roku bojownikom Państwa Islamskiego udało się ponownie przejąć częściowo kontrolę nad okolicami góry Sindżar, co na nowo stworzyło ryzyko dla przebywającej na niej ludności. W grudniu 2014 roku regionalne siły kurdyjskie (Peshmerga) dokonały, w ściślej współpracy z USA i YPG, ofensywy przeciwko ISIS. Wsparcie z powietrza (ok. 50 nalotów) jednostek amerykańskich ułatwiło przerwanie oblężenia. W operacji między 17 a 21 grudnia 2014 roku oddziały kurdyjskie uzyskały częściową kontrolę nad górą i miastem Sindżar. Ponadto działania militarne YPG skutkowały ustanowieniem korytarza umożliwiającego szukającym schronienia jezydom przejście na terytoria kontrolowane przez stronnictwa kurdyjskie w Syrii. Ponowna ofensywa sił kurdyjskich w listopadzie 2015 roku zakończyła się całkowitym przejęciem przez nich władzy nad dystryktem i odrzuceniem sił ISIS.

Konkluzja na temat charakteru operacji humanitarnej w obronie jezydów i udzielenie odpowiedzi na pytanie o to, ile elementów interwencji humanitarnej bądź odpowiedzialności za ochronę można w niej odnaleźć, wymaga wskazania na podstawowe różnice między koncepcjami interwencji humanitarnej a odpowiedzialności za ochronę. Dodatkowym, pomocniczym dla dalszej analizy zabiegiem analitycznym będzie próba kwalifikacji naruszeń praw człowieka.

${ }_{18}$ Patrz m.in. H. SiddiQue: 20000 Iraqis Besieged by Isis Escape from Mountain after US Air Strikes. "The Guardian”, 10 August 2014 — https:/www.theguardian.com/world/2014/ aug/10/iraq-yazidi-isis-jihadists-islamic-state-kurds (dostęp: 21.06.2018). Część uchodźców zdecydowała się na przekroczenie granicy z Turcją, która we wspomnianym okresie również dostarczała pomocy humanitarnej jezydom.

${ }^{19}$ K. DeYoung, C. Whitlock: Rescue Mission for Yezidis on Iraq's Mount Sinjar Appears Unnecessary, Pentagon Says. "The Washington Post", 14 August 2014 - https:// wapo.st/2yRLUeQ (dostęp: 21.06.2018). 
Przez interwencję humanitarną należy rozumieć użycie siły poza granicami kraju przez określony podmiot (najczęściej państwo lub grupe państw) w celu zapobieżenia poważnym i masowym naruszeniom fundamentalnych praw jednostek innych niż obywatele państwa interweniującego bez zgody tego państwa, na którego terytorium użyto siły ${ }^{20}$. Użycie siły może być autoryzowane przez odpowiednią organizację międzynarodową, a dodatkowym czynnikiem legitymizacyjnym jest spełnienie tzw. kryteriów interwencji humanitarnej (np. zasady proporcjonalności i bezstronności, humanitarnego skutku, humanitarnego celu, wyczerpania środków pokojowych) ${ }^{21}$. Odpowiedzialność za ochronę (Responsibility to Protect, R2P) traktowana jest jako koncepcja wyrosła na gruncie interwencji humanitarnej. Za jej podstawowy element definicyjny uważa się zobowiązanie państw do zapewnienia ochrony ludności przed ludobójstwem, zbrodniami przeciwko ludzkości, czystkami etnicznymi i zbrodniami wojennymi oraz gotowość Narodów Zjednoczonych do podjęcia kolektywnego działania (także na podstawie rozdz. VII), jeśliby państwa okazały się niezdolne do realizacji wspomnianego wcześniej zobowiązania ${ }^{22}$. R2P ma swoje dwa rozumienia: pierwsze, związane jest z raportem Międzynarodowej Komisji ds. Interwencji i Suwerenności Państwa, drugie, dotyczy przeformułowania koncepcji w wyniku raportów sekretarza generalnego ONZ i debat w Zgromadzeniu Ogólnym. Efektem prac ONZ są między innymi tzw. filary R2P (odpowiedzialność państwa za ochronę ludności, wsparcie państw przez społeczność międzynarodową, reakcja ONZ na naruszenia) ${ }^{23}$. Różnice między interwencją humanitarną a odpowiedzialnością za ochronę (zarówno w rozumieniu ICISS, jak i ONZ) zawiera tabela 1 .

Warto zauważyć, że obie koncepcje znacznie więcej łączy niż dzieli, przy czym różnice powstają najczęściej w wyniku konkretyzacji cech interwencji humanitarnej i R2P. Obie mają charakter powinnościowy (poważne naruszenia praw człowieka uruchamiają w założeniach oba mechanizmy), obejmują użycie siły (aczkolwiek akcentuje je silniej interwencja humanitarna), są reakcją na poważne naruszenia praw człowieka (konkretnie zdefiniowane w przypadku R2P), dokonywane są formalnie w imieniu społeczności międzynarodowej (przy czym w R2P w rozumieniu ONZ interwencja jest możliwa jedynie na podstawie decyzji Rady Bezpieczeństwa) i realizowane są głównie przez mocarstwa. Odpowie-

20 J.L. Holzgrefe: The Humanitarian Intervention Debate. In: Humanitarian Intervention: Ethical, Legal, Political Dilemmas. Eds. J.L. Holzgrefe, R. Keohane. Cambridge 2003, s. 13.

${ }^{21}$ Patrz m.in. A. Domaga£a: Interwencja humanitarna $w$ stosunkach międzynarodowych. Bydgoszcz - Wrocław 2008, s. 94-101.

${ }_{22}$ Summit Outcome Document, 16 September 2005. UN Doc. A/RES/60/1, para. 138140.

${ }^{23}$ Więcej na ten temat A. Domagala: Od interwencji humanitarnej do odpowiedzialności za ochronę. Kraków 2016, s. 49-113. 


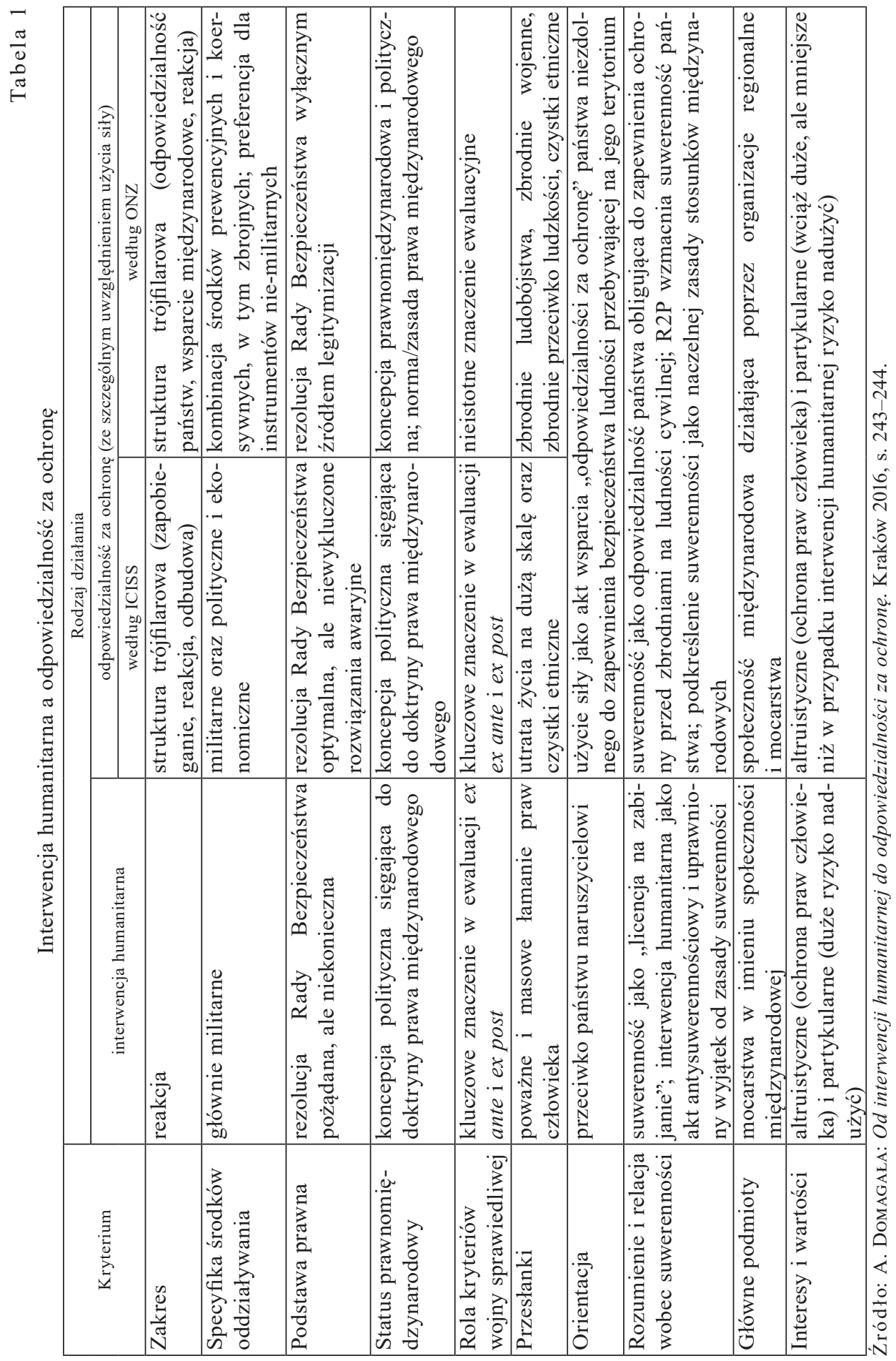


dzialność za ochronę próbuje redukować zagrożenia wynikające z interwencji humanitarnej odnoszące się do kwestii legitymizacji oraz złożonej motywacji potencjalnych interwentów. R2P w rozumieniu ONZ (w przeciwieństwie do $\mathrm{R} 2 \mathrm{P}$ w rozumieniu ICISS) jednoznacznie rozprawia się z unilateralną interwencją humanitarną, podejmowaną bez zgody Rady Bezpieczeństwa, uznając ją za niedopuszczalną i sprzeczną z prawem międzynarodowym. Skrupulatna ocena sytuacji w łonie organów ONZ zmniejsza również ryzyko interwencji podejmowanej na podstawie przesłanek nie tylko humanitarnych albo wręcz takich, w których naruszenia praw człowieka są jedynie pretekstem uzasadniającym interwencję $\mathrm{w}$ wewnętrzne sprawy państw.

Kwalifikacja naruszeń wobec jezydów, pomijając oczywiste ograniczenia (ostateczne słowo na ten temat należy do organów sądowych), wydaje się stosunkowo prostym zadaniem. Najczęstszym określeniem padającym w kontekście ataków było ludobójstwo ${ }^{24}$. Państwu Islamskiemu przypisuje się zamiar wyniszczenia jezydów i dokonywane z taką intencją masowe zabójstwa. Zmuszanie do konwersji może być interpretowane jako rozmyślne stwarzanie okoliczności mających skutkować wyniszczeniem grupy, ponieważ tożsamość jezydów związana jest nieodłącznie z ich wyznaniem (innymi słowy jezyda, który dokonał konwersji, przestawał być jezydą) ${ }^{25}$. Kategoria ludobójstwa, najczęściej w formule „ryzyko ludobójstwa”, „czynów potencjalnie stanowiących ludobójstwo" albo podobnych, padła w wielu oświadczeniach i dokumentach. Były to między innymi przemówienie prezydenta USA z 7 sierpnia 2014, uchwała Izby Reprezentantów USA z 14 marca 2016 roku $^{26}$, rezolucja Parlamentu Europejskiego z 4 lutego 2016 roku $^{27}$, raport Wysokiego Komisarza Praw Człowieka Narodów Zjednoczonych ${ }^{28}$ czy raport Komisji Śledczej ONZ ds. Syrii z czerwca 2016 roku $^{29}$. Część z organizacji międzynarodowych określała ataki na jezydów i inne działania ISIS w dystrykcie Sindżar jako zbrodnie przeciwko ludzkości

${ }^{24}$ Konwencja w sprawie zapobiegania i karania zbrodni ludobójstwa, uchwalona przez Zgromadzenie Ogólne Narodów Zjednoczonych dnia 9 grudnia 1948 r. (ratyfikowana zgodnie z ustawą z dnia 18 lipca 1950 r.). Dz.U. 1952, nr 2, poz. 9.

${ }_{25}$ Patrz m.in. Report of the Office of the United Nations High Commissioner for Human Rights on the human rights situation in Iraq..., s. 5-6, para. 17.

${ }^{26}$ H.Con.Res.75, March 15, 2016 - https://www.congress.gov/bill/114th-congress/hou se-concurrent-resolution/75/text (dostęp: 21.06.2018). W rezolucji określono zbrodnie ISIS wprost jako ludobójstwo, zbrodnie przeciwko ludzkości i zbrodnie wojenne.

27 European Parliament Resolution of 4 February 2016 on the Systematic Mass Murder of Religious Minorities by the So-called 'ISIS/Daesh'. P8 TA (2016) 0051 — https://bit. ly/1U2JXhw (dostęp: 22.06.2018).

${ }^{28}$ Report of the Office of the United Nations High Commissioner for Human Rights on the human rights situation in Iraq..., s. 5, para. 15-16.

${ }^{29}$ Human Rights Council: "They came to destroy": ISIS Crimes Against the Yazidis. UN Doc. A/HRC/32/CRP.2, 15 June 2016, s. 20-31 - https://ohchr.org/Documents/HRBo dies/HRCouncil/CoISyria/A_HRC_32_CRP.2_en.pdf (dostęp: 22.06.2018). 
lub zbrodnie wojenne. Ostatnia kwalifikacja wydaje się najmniej ryzykowna ISIS dokonywało wielokrotnie czynów sprzecznych - co łatwo wykazać z międzynarodowym prawem humanitarnym. Uznanie za zbrodnie przeciwko ludzkości, definiowane jako systematyczny lub na szeroką skalę atak na ludność cywilną, wymaga pewnej arbitralności. Niemniej jednak uczynili tak między innymi Liga Państw Arabskich 10 sierpnia 2014 roku, Rada Bezpieczeństwa w rezolucji 2170 z 15 sierpnia 2014 roku, a kilka miesięcy później Wysoki Komisarz Praw Człowieka Narodów Zjednoczonych wraz z misją ONZ w Iraku ${ }^{30}$. $\mathrm{Z}$ powyższej krótkiej analizy stosunku przedstawicieli społeczności międzynarodowej do naruszeń w Sindżarze można wyciągnąć wniosek, że spełniona jest podstawowa przesłanka zaangażowania społeczności międzynarodowej, bez względu na to, czy mowa o interwencji humanitarnej, czy odpowiedzialności za ochronę (w rozumieniu zarówno ICISS, jak i ONZ).

Użycie siły podjęte w sierpniu 2014 roku przez Stany Zjednoczone nie może być uznane za interwencję humanitarną, jako że USA uczyniły to na prośbę irackiego rządu i tym samym dysponowały zgodą suwerennych władz na operację militarną na terytorium Iraku. Przedstawiciele Iraku wielokrotnie wystosowywali prośby do Stanów Zjednoczonych dotyczące wykorzystania potencjału militarnego w celu ochrony integralności terytorialnej Iraku oraz ludności zamieszkującej irackie terytorium. Pierwsza nieformalna prośba została wystosowana 11 czerwca 2014 roku, a kolejna — już oficjalna — przez ministra spraw zagranicznych Hoshyara Zebari'ego - 18 czerwca 2014 roku $^{31}$. Irak publicznie potwierdzał współpracę z USA w zwalczaniu Państwa Islamskiego oraz zgodę na użycie siły dla sił amerykańskich na forum $\mathrm{ONZ}^{32}$. Interwencja w obronie jezydów przeprowadzona przez USA po 7 sierpnia 2014 roku była więc interwencją na zaproszenie. Jej status w doktrynie prawa międzynarodowego nie jest w pełni klarowny, ale zdecydowanie dominuje podgląd, że nie sposób zabronić państwu (ipso facto suwerennemu) zwrócenia się do dowolnego państwa,

30 Report on the Protection of Civilians in Armed Conflict in Iraq..., s. 3; Arab League Denounces ISIS attacks as “crimes against humanity”. „Al-Arabija News”, 11 August 2014 - https://english.alarabiya.net/en/News/middle-east/2014/08/11/U-S-weighs-optionsto-evacuate-trapped-Yazidis-.html (dostęp: 22.06.2018); Security Council Resolution 2170. UN Doc. S/RES/2170 (2014), 15 August 2014 — http://unscr.com/en/resolutions/doc/2170, (dostęp: 22.06.2018).

31 A. Entous, J. Barnes: Iraq Signals Openness to U.S. Airstrikes Against al-Qaeda, U.S. Officials Say. "The Wall Street Journal”, 11 June 2014 — https://archive.li/jFoMh (dostęp: 26.06.2018); C. GraY: International Law and the Use of Force. New York 2018, s. 87.

32 Patrz m.in. sygnowany przez ministra spraw zagranicznych Ibrahima al-Uszajkira al-Dżafariego list rządu Iraku do Rady Bezpieczeństwa ONZ z 20 września 2014 r. Letter dated 20 September 2014 from the Permanent Representative of Iraq to the United Nations addressed to the President of the Security Council — https://www.securitycouncilreport. org/atf/cf/\%7B65BFCF9B-6D27-4E9C-8CD3-CF6E4FF96FF9\%7D/s_2014_691.pdf (dostęp: 10.01.2019). 
by podjęło działania na terytorium państwa zapraszającego. W konsekwencji działanie takie nie następuje wbrew woli państwa, a więc $\mathrm{z}$ definicji nie jest interwencją humanitarną ${ }^{33}$.

Szeroko rozumiane działania militarne USA w Iraku trudno uznać również za przejaw trzeciego filaru odpowiedzialności za ochronę, a jedynie pod pewnymi warunkami mogą być egzemplifikacją drugiego filaru R2P (w rozumieniu ONZ). Odpowiedzialność za ochronę z założenia jest zespołem działań skoncentrowanych na zapobieganiu naruszeniom i niedopuszczeniu do poważnych naruszeń praw człowieka. Tymczasem użycie siły wskazuje jednoznacznie nie na prewencję, ale na reakcję na zbrodnie ISIS. Uwzględniając to, należy zauważyć, że trzeci filar R2P dotyczy polityczno-militarnej reakcji na naruszenia inicjowanej i autoryzowanej przez ONZ, czego Irak (ale także USA) zamierzał uniknąć. Działania Stanów Zjednoczonych, zwłaszcza te poprzedzające użycie siły, można by określić jako wsparcie dla Iraku w celu zapobieżenia zbrodni. Nie należy zapominać jednak, że doktryna R2P mówi o wsparciu ze strony społeczności międzynarodowej. Jeśli pomoc ze strony pojedynczych państw można uznać za pomoc społeczności międzynarodowej, to wysłanie personelu wojskowego przed rozpoczęciem interwencji w obronie jezydów można określić jako odpowiedzialność za ochronę. Warto podkreślić, że adresatem międzynarodowej pomocy był zarówno iracki rząd, jak i kurdyjskie organizacje w Iraku (z rządem regionalnym i Peshmergą na czele), a owa asysta może być interpretowana w kontekście R2P jako chęć zatrzymania zbrodni oraz zapobieżenia w przyszłości naruszeniom ze strony ISIS.

Konkludując, użycie sił zbrojnych przez USA w obronie jezydów w latach 2014-2015 nie jest ani interwencją humanitarną, ani trzecim filarem odpowiedzialności za ochronę ${ }^{34}$. Nie oznacza to jednak, że w operacji w obronie jezydów nie można dostrzec elementów interwencji humanitarnej. Po pierwsze, Stany Zjednoczone w zwalczaniu Państwa Islamskiego i powstrzymywaniu naruszeń wobec jezydów nie ograniczyły się do użycia siły na terytorium Iraku.

${ }_{33}$ Problem, na jaki się wskazuje, dotyczy dwóch kwestii. Po pierwsze, wymuszonej zgody na użycie siły (poddaniu państwa silnej politycznej lub ekonomicznej presji), po drugie, uzyskania zgody na wkroczenie ze strony rządu, którego legitymizacja wewnętrzna jest wątpliwa. W przypadku Iraku nie zachodzi ani pierwsza, ani druga sytuacja. Patrz m.in. M. Byrne: Consent and the Use of Force. An Examination of 'intervention by invitation' as a Basis for US Drone Strikes in Pakistan, Somalia and Yemen. "Journal on the Use of Force and International Law" 2016, Vol. 3, Issue 1, s. 97-125; K. BANneKer-Christakis: Military Interventions against ISIL in Iraq, Syria and Libya, and the Legal Basis of Consent. "Leiden Journal of International Law" 2016, Vol. 29, Issue 3, s. 744-745.

${ }^{34}$ Por. G. Evans: The Right Iraqi Intervention. "Project Syndicate", 14 August 2014 https://bit.ly/2IB6Y8N (dostęp: 26.06.2018). Evans, jeden z architektów R2P, utrzymuje (nie przeprowadzając jednak w przekonaniu autora artykułu przekonującego wywodu), że zachodzi zgodność interwencji w 2014 roku z zasadami R2P. Ze zdaniem Evansa można się częściowo zgodzić jedynie w kontekście R2P w rozumieniu ICISS. 
Od września 2014 roku siły amerykańskie zaczęły atakować z powietrza cele ISIS w Syrii, co miało bezpośredni związek z operacją na rzecz jezydów. USA tłumaczyły swoje działania przed organami ONZ „chęcią ochrony obywateli irackich” poprzez „konieczne i proporcjonalne” działania militarne w Syrii ${ }^{35}$. Miało to szczególne znaczenie dla sukcesu grudniowej ofensywy kurdyjskiej i przerwania kolejnego oblężenia góry Sindżar. Ataki z powietrza wymierzone w instalacje, pojazdy i bojowników Państwa Islamskiego w Syrii nie miały legitymizacji ani w postaci zgody syryjskiego rządu, ani odpowiedniej rezolucji Rady Bezpieczeństwa. Oznacza to, że takie działania militarne USA zorientowane na ochronę ludności jezydzkiej (czy szerzej irackiej bądź kurdyjskiej) mogą być jednoznacznie uznane za interwencję humanitarną.

Stany Zjednoczone nie były jedynym znaczącym aktorem zewnętrznym w operacji humanitarnej na rzecz jezydów. Jeśli status prawny zaangażowania militarnego Australii czy Wielkiej Brytanii wydaje się jasny (podobny do amerykańskiego) ${ }^{36}$, to więcej kontrowersji pojawia się w kontekście działań YPG. Nie wnikając w nieformalne porozumienia i kontakty między irackimi władzami i USA a kurdyjskimi organizacjami (para)militarnymi (które zapewne miały miejsce), trzeba stwierdzić, że brakowało informacji o zgodzie Iraku na prowadzenie operacji z wykorzystaniem sił zbrojnych ze strony zagranicznych podmiotów niepaństwowych. Biorąc pod uwagę charakter zaangażowania jednostek YPG w trakcie akcji ewakuacyjnej z góry Sindżar w sierpniu 2014 roku oraz udział w ofensywie przeciwko ISIS w grudniu 2014 roku (utworzenie korytarza humanitarnego do Syrii), należy uznać je za specyficzny przykład interwencji humanitarnej.

Z perspektywy odpowiedzialności za ochronę w rozumieniu ONZ podstawowym niedostatkiem operacji w obronie jezydów jest brak rezolucji Rady Bezpieczeństwa jako podstawy prawnej do użycia siły. Bardziej elastyczni w tym względzie byli twórcy raportu ICISS, którzy dopuszczali inne rozwiązania legitymizacyjne, aczkolwiek unikali za wszelką cenę aprobaty dla rozwiązań unilateralnych, do których de facto doszło w przypadku niesienia pomocy jezydom. Operacja humanitarna na rzecz jezydów stanowi w oczywisty sposób reakcję na naruszenia ze strony ISIS, co w znacznie większym stopniu jest zgodne z koncepcją R2P w rozumieniu ICISS, aniżeli z akcentującą prewencję koncepcją w rozumieniu ONZ. Użycie siły przez USA w obronie jezydów należy uznać

${ }^{35}$ Letter from the Permanent Representative of the United States of America to the United Nations addressed to the Secretary General. UN Doc. S/2014/695, 23 September 2014, http://repository.un.org/bitstream/handle/11176/89298/S_2014_695-EN. pdf?sequence=21\&isAllowed=y, (dostęp: 26.06.2018).

${ }^{36}$ Patrz m.in. H. Stuart: Legal Case for British Military Action Against Islamic State in Iraq and Syria. "Centre for the Response to Radicalisation and Terrorism. Policy Paper" 2014, No. 2 s. 3, — http://henryjacksonsociety.org/wp-content/uploads/2014/10/Legal-Casefor-British-Military-Action-in-Iraq-and-Syria.pdf (dostęp: 25.06.2018). 
przede wszystkim za interwencję na zaproszenie, dla której wprawdzie nie ma miejsca w doktrynie R2P, ale która co do zasady nie jest sprzeczna z prawem międzynarodowym. Punktem wspólnym oenzetowskiej R2P i operacji USA w północno-zachodnim Iraku jest podkreślanie suwerenności jako konceptu organizującego relacje między państwami (choć ta uwaga nie dotyczy wszystkich aktorów w regionie). Niemniej jednak wyrażenie zgody na użycie siły konkretnym państwom (np. USA i Wielkiej Brytanii), a nie społeczności międzynarodowej utożsamianej z ONZ wchodzi w kolizję z głównymi zasadami odpowiedzialności za ochronę.

Przykład operacji humanitarnej w obronie jezydów wskazuje, jak trudno przyporządkować praktykę używania siły w celach humanitarnych do powszechnie stosowanych konceptów. W interwencji w 2014 roku ze względu na wielość podmiotów biorących udział w akcji na rzecz jezydów i złożoną sytuację polityczno-prawną na pograniczu syryjsko-irackim, wyróżnić można, oprócz dominującego typu działania (interwencji na zaproszenie), także zaskakująco dużo elementów interwencji humanitarnej (głównie w aktywności militarnej YPG w Iraku oraz USA w Syrii). W stopniu najmniejszym operacja w obronie jezydów zawiera cechy odpowiedzialności za ochronę w rozumieniu ONZ.

\section{Bibliografia}

Amnesty International: Ethnic Cleansing on a Historic Scale: Islamic State's Systematic Targeting of Minorities in Northern Iraq. London 2014.

Arab League Denounces ISIS attacks as “crimes against humanity”. „Al-Arabija News”, 11 August 2014 — https://english.alarabiya.net/en/News/middle-east/2014/ 08/11/U-S-weighs-options-to-evacuate-trapped-Yazidis-.html (dostęp: 22.06.2018).

Asatrian G.S., Arakelova V.: The Religion of the Peacock Angel. The Yezidis and their Spirit World. Abingdon-New York 2014.

BANNEKER-Christakis K.: Military Interventions against ISIL in Iraq, Syria and Libya, and the Legal Basis of Consent. "Leiden Journal of International Law" 2016, Vol. 29, Issue 3.

Byrne M.: Consent and the Use of Force. An Examination of 'intervention by invitation' as a Basis for US Drone Strikes in Pakistan, Somalia and Yemen. "Journal on the Use of Force and International Law" 2016, Vol. 3, Issue 1.

Cetorelli V., Sasson I., Shabila N., Burnham G.: Mortality and Kidnapping Estimates for the Yezidis Population in the Area of Mount Sinjar, Iraq, in August 2014: A Retrospective Household Survey. „PLoS Med” 2017, Vol. 14, No 5 https://doi.org/10.1371/journal.pmed.1002297 (dostęp: 20.06.2018).

Clark I.: Legitimacy in International Society. Oxford 2007. 
Colt N.: Thousands Find Shelter in Iraqi Kurdistan after Escaping Mount Sinjar. UNHCR, 12 August 2014 — http://www.unhcr.org/news/latest/2014/8/53e9fe2 d9/thousands-find-shelter-iraqi-kurdistan-escaping-mount-sinjar.html (dostęp: 21.06.2018).

DeYoung K., Whitlock C.: Rescue Mission for Yezidis on Iraq's Mount Sinjar Appears Unnecessary, Pentagon Says. "The Washington Post", 14 August 2014 — https://wapo.st/2yRLUeQ (dostęp: 21.06.2018).

DomagaŁA A.: Interwencja humanitarna $w$ stosunkach międzynarodowych. Bydgoszcz-Wrocław 2008.

DomagaŁa A.: Od interwencji humanitarnej do odpowiedzialności za ochronę. Kraków 2016.

Entous A., Barnes J.: Iraq Signals Openness to U.S. Airstrikes Against al-Qaeda, U.S. Officials Say. "The Wall Street Journal”, 11 June 2014 — https://archive.li/ jFoMh (dostęp: 26.06.2018).

European Parliament Resolution of 4 February 2016 on the Systematic Mass Murder of Religious Minorities by the So-called 'ISIS/Daesh'. P8 TA (2016) 0051 https://bit.ly/1U2JXhw (dostęp: 22.06.2018).

Evans G.: The Right Iraqi Intervention. "Project Syndicate", 14 August 2014 https://bit.ly/2IB6Y8N (dostęp: 26.06.2018).

Fiott D., Koops J.: The Responsibility to Protect and the Third Pillar. Basingstoke 2015.

GRAY Ch.: International Law and the Use of Force. New York 2018.

H.Con.Res.75, March 15, 2016 — https://www.congress.gov/bill/114th-congress/ house-concurrent-resolution/75/text (dostęp: 21.06.2018).

Holzgrefe J.L.: The Humanitarian Intervention Debate. In: Humanitarian Intervention: Ethical, Legal, Political Dilemmas. Eds. J.L. Holzgrefe, R. Keohane. Cambridge 2003.

Howard M.: "They won't stop until we are all wiped out". Among the Yezidi, a People in Mourning. "The Guardian", 18 August 2007 - https://www.theguardian.com/world/2007/aug/18/iraq.topstories3 (dostęp: 20.06.2018).

Humanitarian Intervention: Ethical, Legal, Political Dilemmas. Eds. J.L. HolzGReFe, R. Keohane. Cambridge 2003.

Human Rights Council: "They came to destroy": ISIS Crimes Against the Yazidis. UN Doc. A/HRC/32/CRP.2, 15 June 2016.

Human Rights Office of the High Commissioner for Human Rights \& United Nations Assistance Mission for IraQ: Report on the Protection of Civilians in Armed Conflict in Iraq: 6 July - 10 September 2014, October 2014 — https:// www.ohchr.org/Documents/Countries/IQ/UNAMI_OHCHR_POC_Report_ FINAL_6July_10September2014.pdf (dostęp: 20.06.2018).

Human Rights Watch: Iraq: Forced Marriage, Conversion for Yezidis. Victims, Witnesses Describe Islamic State's Brutality to Captives, 11 October 2014 https://www.hrw.org/news/2014/10/11/iraq-forced-marriage-conversion-yezidis (dostęp: 20.06.2018).

Iraq Crisis: ISIS Militiants Threaten UK, Says Cameron. "BBC News", 19 June 2014 — https://www.bbc.com/news/uk-politics-27898724 (dostęp: 20.06.2018). 
Konwencja w sprawie zapobiegania i karania zbrodni ludobójstwa, uchwalona przez Zgromadzenie Ogólne Narodów Zjednoczonych dnia 9 grudnia 1948 r. (ratyfikowana zgodnie z ustawą z dnia 18 lipca 1950 r.). Dz.U. 1952, nr 2, poz. 9.

Letter Dated 20 September 2014 from the Permanent Representative of Iraq to the United Nations Addressed to the President of the Security Council - https:// www.securitycouncilreport.org/atf/cf/\%7B65BFCF9B-6D27-4E9C-8CD3-CF6E4FF96FF9\%7D/s_2014_691.pdf (dostęp: 10.01.2019).

Letter from the Permanent Representative of the United States of America to the United Nations Addressed to the Secretary General. UN Doc. S/2014/695, 23 September 2014 — http://repository.un.org/bitstream/handle/11176/89298/ S_2014_695-EN.pdf?sequence=21\&isAllowed=y (dostęp: 26.06.2018).

Morris L.: Islamic State Seizes Town of Sinjar, Pushing out Kurds and Sending Yazidis fleeing. "The Washington Post", 3 August 2014 — https://wapo.st/2Kquasd (dostęp: 23.06.2018).

Otтеn C.: Slaves of Isis. The Long Walk of the Yazidi Women. "The Guardian", 25 July 2017 — https://www.theguardian.com/world/2017/jul/25/slaves-of-isisthe-long-walk-of-the-yazidi-women (dostęp: 20.06.2018).

Pattison J.: Humanitarian Intervention \& the Responsibility to Protect. Who Should Intervene? New York 2010.

PitParinen T.: Responsibility to Protect. The Coming of Age of Sovereignty-Building. "Civil Wars" 2013, Vol. 15, Issue 3.

Report of the Office of the United Nations High Commissioner for Human Rights on the Human Rights Situation in Iraq in the Light of Abuses Committed by the So-called Islamic State in Iraq and the Levant and Associated Groups. UN Doc. A/HRC/28/18, 13 March 2015.

Rubin A.J., Arango T., Cooper H.: U.S. Jets and Drones Attack Militants in Iraq Hoping to Stop Advance. "New York Times", 8 August 2014 — https://www. nytimes.com/2014/08/09/world/middleeast/iraq.html (dostęp: 21.06.2018).

Salin M.A.: Iraq's Christians Seek Refuge with Kurds. „Al Jazeera News”, 26 June 2014 - https://www.aljazeera.com/news/middleeast/2014/06/iraq-christians-se ek-refuge-with-kurds-2014624867119947.html (dostęp: 20.06.2018).

Security Council Resolution 2170. UN Doc. S/RES/2170 (2014), 15 August 2014 http://unscr.com/en/resolutions/doc/2170 (dostęp: 22.06.2018).

SidDIQUE H.: 20000 Iraqis Besieged by Isis Escape from Mountain after US Air Strikes. "The Guardian", 10 August 2014 — https://www.theguardian. com/world/2014/aug/10/iraq-yazidi-isis-jihadists-islamic-state-kurds (dostęp: 21.06.2018).

Stuart H.: Legal Case for British Military Action Against Islamic State in Iraq and Syria. "Centre for the Response to Radicalisation and Terrorism, Policy Paper" 2014, No 2 - http://henryjacksonsociety.org/wp-content/uploads/2014/10/LegalCase-for-British-Military-Action-in-Iraq-and-Syria.pdf (dostęp: 25.06.2018).

Summit Outcome Document, 16 September 2005. UN Doc. A/RES/60/1, para. 138 140.

United Nations High Commissioner for Human Rights \& United Nations Assistance Mission for Iraq: A Call for Accountability and Protection: 
Yezidi Survivors of Atrocities Committed by ISIL, August 2016 - https://www. ohchr.org/Documents/Countries/IQ/UNAMIReport12Aug2016_en.pdf (dostęp: 21.06.2018).

Watson I., Starr B., Carter C.J.: Officials: More U.S. Advisers Being Sent to Iraq. "CNN News", 13 August 2014 — https://edition.cnn.com/2014/08/12/world/ meast/iraq-crisis/index.html?hpt=hp_t1 (dostęp: 21.06.2018).

The White House Office of the Press Secretary: Statement by the President. 7 August 2014 - https://obamawhitehouse.archives.gov/the-press-office/2014/08/07/statement-president (dostęp: 21.06.2018).

Arkadiusz Domagała — dr hab. nauk społecznych w dyscyplinie nauk o polityce, adiunkt w Zakładzie Badań nad Konfliktami i Przemocą Politycznymi Instytutu Politologii Uniwersytetu Wrocławskiego. Zainteresowania naukowe: poważne i masowe naruszenia praw człowieka, interwencja humanitarna, międzynarodowa ochrona praw człowieka, integracja europejska. 